\title{
Genocide in the Liberation War of Bangladesh: A Case Study on Charkowa Genocide
}

\author{
Mohammad Abdul Baten Chowdhury \\ Assistant Professor, \\ Department of History \& Civilization, University of Barishal, Barishal-8254, Bangladesh \\ Md. Al-Amin* \\ Assistant Professor, \\ Department of Political Science, University of Barishal, Barishal-8254, Bangladesh
}

\begin{abstract}
The liberation war and the genocide of Bangladesh in 1971 are becoming the core research interest among genocide researchers, but the genocide in Charkowa has hardly been explored. As because of this, the current paper intended to explore the true history of the Charkowa genocide, where it found that on 20 August 1971 the Pakistani Army attacked the innocent people of Charkowa village and killed 16 people at the bank of Maragangi canal along with arson and looting of their homes and shops. The strategy was very obvious that it was a politicide type of genocide, where they wanted to destroy the support base of Mukti Bahini and the freedom fighters as well.
\end{abstract}

Keywords: Genocide, Liberation War and Charkowa

DOI: $10.7176 /$ RHSS/11-6-02

Publication date:March $31^{\text {st }} 2021$

\section{Introduction}

Genocide in the 20th century became a common and so systematic and carried out most brutal activity "beginning with the deportation of Armenians from Ottoman territory, which may have taken the lives of as many as 1.8 million people in 1915. Nazi Germany engaged in mass extermination on a scale never seen before,"(Horvitz, Leslie Alan and Catherwood, 2006, p. 166) but the term was first used by "Polish lawyer Raphäel Lemkin in 1944 in his book Axis Rule in Occupied Europe, ”(UN, 2020) furthermore after then it has been frequently termed in case of every mass destruction. Literally, the genocide is the ubiquitous word, which is generally used in "the attempted destruction of human groups, but also rhetorically in the form of a word that is at once universally known and widely invoked perhaps because it is frequently misunderstood."(Bloxham, Donald and Moses, 2010, p. 1) Formally, the present convention illustrated it as several destructive acts which commit to annihilate whole or part of a nation, ethnic or religious groups, in such activities includes, "(a) Killing members of the group; (b) Causing serious bodily or mental harm to members of the group; (c) Deliberately inflicting on the group conditions of life calculated to bring about its physical destruction in whole or in part; (d) Imposing measures intended to prevent births within the group; (e) Forcibly transferring children of the group to another group."(UN, 1951, p. 1) In this piece of discussion we would like to use the term genocide in case of mass killing which was committed by the Pakistani army against the Bangladeshi or Bangali people in the name of "Operation Searchlight" in 1971.

Genocide is a tragic chapter in the history of the liberation war of Bangladesh. On the night of March 25, 1971, the Pakistani aggressors made a scandalous history in the world by carrying out infernal massacres of innocent and unarmed civilians in the major cities of the country including Dhaka. Torture and destruction go hand in hand with genocide. In the nine months from March 25 to December 16, 1971, more than 3 million people were killed and more than 4 lac women were raped. (Sheren, 2015) In this war "the genocide committed by the Pakistan army is one of the worst holocausts in world history,"(Quaderi, 2015) which took across the whole Bangladesh. As part of this, during the war of liberation genocide, torture, looting and arson took place in 10 Upazilas of Barishal district. The massacre was led by Pakistani forces and their local allies, members of the Peace Committee, Razakars, Al-Badar and Al-Shams forces. On August 20, 1971, the Pakistani army fired two cells from the Naval Jetty on the Kirtankhola River towards Charkowa Union. Then a group of 30/40 people crossed the river and reached the ferry terminal of Charkowa Union. On that day, about 18 people were shot dead at Maragangi Khalpar(Bank of Canal) in Charkowa Union. At the same time, looting and arson took place in shops, businesses and localities. However, here does not seem to be much discussion about this ruthless genocide of the liberation war, which is also very true about the books written about the liberation war of Barishal. Most strikingly, even in the book Muktiyuddha Kosh edited by Muntasir Mamun, where he illustrated and mentioned about 8 genocides of Barishal but not a single word written about this selected genocide. Besides, several other scholars who studied the genocide of Barishal in which Sirajuddin Ahmed is one of the prominent figure, but surprisingly he also didn't heed on this issue. Whereas only a very small extent about this incident 
mentioned in an article written by Md. Moniruzzaman Shaheen, which is "Barishal 1971: History and Nature of Genocide," but not a large extent by which one could know about this ruthless genocide.In this regard, this piece intended to explore the details about the Charkowa genocide, whereas there will be an attempt to delve into its historical background and level of torture and number of the killed people by the Pakistani Army as well as the strategy of genocide and details about destructed people in this genocide.

\section{Methodology and Data Sources}

Methodologically this research work conducted through historical method, whereas the interview method also applied. Both the primary and secondary sources of data used in this paper, but basically it emphasised on primary sources of data. In the case of primary data, we interviewed eyewitnesses, family members of the martyrs and the families of the victims and freedom fighters. We used audio, video recorder and camera while collecting information on the spot. In the case of secondary data, on the other hand, Published and unpublished books, articles, journals, newspapers and several other online data sources like website, video and audio content which are related to the liberation war and genocide of Bangladesh were also used, where it was necessary. Interviews, on the one hand, were conducted at the Union Charkowa in Barishal district, especially it focussed on the eyewitnesses, freedom fighters, family members of the victims and martyrs of the Charkowa village, where more than 20 eyewitnesses, several freedom fighters and numbers of family members of the victims were selected as a sample or specimen through quota sampling, those who are closely connected with this genocide to meet up the information. Finally, the collected data systemized and analysed through different software for the final manuscript.

\section{Historical Background of Genocide in Charkowa}

If we look back to the social, political and geographical conditions of Charkowa Union in the lense of 1971's background comparing with other area of Barishal, it was considered as a neglected area. This union is situated on the banks of the river Kirtankhola and at that time all the roads in this area were unpaved, where usually, people used to walk on foot. If anybody wanted to come to Barishal city from the union, they had to be fussy. For this purpose ferries (Kheya) were built on both sides of the river. This ferry was one of the major trading centres of the Charkowa Union at that time. Due to being a riverside union, many areas of the union are now submerged in the riverbed of Kirtankhola. In 1971, the people of this area were engaged with several types of business including ice factory, leather godown and fish market were their basic business. But none of these exists today and the only reason for this was demolished by the mighty river Kirtankhola. On 20 August 1971, the day the Pak Army carried out killings, looting and arson in the Union, they split into two groups, one group of them entered into the Charkowa Union through the ferry and the other through the ice factory. At that time, the main occupation of the people of this union was agriculture, along with this, the people of the area also had some other earning opportunities as fishermen and boatmen. However, many people here used to run their families by raising animals. The education rate in Charkaua Union was very low and there wasn't any vast educational institution, which could be mentioned except a madrasa and a primary school. At present, the madrasa is on the verge of disappearing into the riverbed. Some small canals still flow through the union. In particular, the canal on the bank of which the massacre was carried out is still flowing in a small range and the canal is a little farther away and joins the Kirtankhola River. This was the only genocide in Charkow in 1971. Besides, no other genocide or any other operation of the Pak army is known or wouldn't be identified yet.

Politically, the people of Barishal have been very conscious since time immemorial. Especially during the revolution against the British period, the people of Barishal joined the Partition of Bengal and the Swadeshi Movement under the banner of 'Swadesh Bandhab'. Later, when the non-cooperation and caliphate movement started, the movement intensified in Barishal under the leadership of Mahatma Ashwini Kumar Dutt. Along with, when the demand for separate land for Muslims arose, many political leaders of the district made a special contribution for establishing Pakistan. In the wake of this demand, when two independent states, India and Pakistan, were born, the people of East Pakistan started revolution for the freedom movement due to the mountainous disparities between the two parts of Pakistan. The people of Barishal, like other parts of the country, formed strong resistance against exploitation and discrimination of Pakistani rule in every movement like the language movement of 1952, elections in the United Front in 1954, education movement in 1962, the student movement in 1964 and later in the six-point movement of 1966. As the movement intensified, the government started conspiracy against Bangabondhu and Bangali as well and they filed an erroneous case, which is historically known as "the Agartala Conspiracy Case" but was bound to withdraw it in the face of resistance from the Bengalis, and the anti-Ayub mass movement began. During this movement Advocate Mojibur Rahman, MA Gafur Mollah, Abdur Rob Serniabat and other local leaders played an important role in motivating the common people against the Pakistani Junta government. Under the pressure of the mass movement, the government announced the date of the general election in '70. Although the Awami League won a single majority in the election and the situation became critical when the Pakistani government refused to hand over 
power to the Awami League. In this situation, Bangabandhu declared independence indirectly through his speech on March 7, where he proclaimed, " the struggle this time is a struggle of our emancipation, the struggle this time is a struggle for independence"(Quoted in Ministry of Information, 2020, p. 13) and finally before arrested by the Pakistani army on march 26 he directly decleared the independence of Bangladesh.(Rashid, 2018, p. 18) On the other hand, when Yahya Khan instructed the Pakistani army to conduct 'Operation Searchlight' on the night of March 25 to kill innocent unarmed Bengalis, in the meantime, the Bengalis took up arms against the Pakistani barbaric forces responding to Bangabandhu's declaration of independence and the liberation war began. With the organizational activities of Awami League, Student League, NAP, Communist Party and Student Union of Greater Barishal District, a fierce resistance movement was formed against the Pakistani aggressors in every town of this southern district. Besides, Siraj Sikder, the head of the Proletarian Party, set up the main base of the East Bengal workers' movement at the Atghar Kuriana Guava Garden in Pirojpur and with his local allies fought several battles against the occupying forces. The salt, weaving, biri(local cigarette) workers of Jhalokati, the ghat workers of Barishal and the children's organizations encouraged the people to participate in the war through various activities in the spirit of the liberation war. Under the activities of the above-mentioned organizations, various strategies and plans were adopted to conduct the war of liberation in this southern district. After Bangabandhu's declaration of independence on 26 March, the leaders formed an advisory council to achieve independence in the south. An independent secretariat of the 11-member advisory council was set up at Barishal Sadar Girls School. Until the infiltration of Pakistani forces on 26 April, all activities, including law and order in the district, were conducted through the Advisory Council. During the incursion, the Pakistani forces faced resistance at Jhunahar and carried out the massacre at Charbaria. They set up the main camp at Barishal Wapda Colony and later carried out genocide in other Upazilas of the district including Barishal Sadar Upazila. The intensification of the war in this region was concerted efforts of the officials of the alternative administration and the members of the Sangram Parishad. As a strategy to conduct the war, the freedom-fighter took part in the war by dividing the region into several stages. From the mass resistance on March 25 to occupying the Barishal from the enemy on December 8, 1971, some of the current local forces. It could be cited here for example, Siraj Sikder's forces, Jahangir Bahadur's forces, Suicidal forces, naval commandos were organized to liberate Barishal from the grip of the occupying forces. The aforesaid local forces and freedom fighters joined hands and took part in several battles against the Pak army in different parts of Greater Barishal including Chachair, Atghar Kuriana Guava Garden, Babuganj, Gournadi, Kirtipasha, Rajapur. However, in most of the battles, the freedom fighters defeated and killed the barbaric forces. In some places, the freedom fighters were attacked by the Pak aggressors. Although the freedom fighters fought with indomitable morale, all these opposition forces including Jamaat-eIslami and the Muslim League of Greater Barishal, as accomplices of the Pak aggressors, wreaked havoc in various villages of the region. At that time various newspapers and magazines published from Barishal published news of the destruction and economic activities of the invading forces and formed a public opinion against them and inspired the people to join into the war by spreading the news of the victory of the freedom fighters in different places. For nine long months, the killings, looting and destruction that the Pakistani barbaric forces inflicted on these southern villages were limitless. In this ruthless war, about forty thousand people of greater Barishal were killed and several thousand houses and installations were damaged. Greater Barishal, Jhalokati and Pirojpur suffered the most damage. The amount of damage caused by the shelling of the Pak aggressor forces on the Kirtankhola river, road bridges, culverts, bridges, schools and colleges in Barishal cannot be measured in terms of money.(Hasan, 2012, p. 38) Not only that, huge numbers of women being tortured by the barbaric forces in this southern district, which was horrible. The self-sacrifice of two of the seven great heroes of the country, Barishal, inspired the freedom-loving masses at that time. The devastation and irreparable damage inflicted on the entire country in the nine months of the war of liberation devastated the economy of the country. Despite the aforementioned casualties and loss of life, the Bengali nation resisted the invading forces with indomitable zeal and morale. In this war, just as the non-military Bengalis went to war against them and they were mostly unskilled and light-armed, this class of people was the ones, who confessed to the most massacres and tortures, and through their bloody path, independent sovereign Bangladesh emerged.

\section{Genocide in Charkowa}

Pakistani army reached at Barishal and landed para-trooper from plane, at the same time their leading team reached here through gun boat on 25April 1971. As soon as they came to Barishal, they set up their headquarters at the office of the Water Development Board and from this head quarter, they used to go to operate every day by car or gunboat. As part of this, on 20 August, a large contingent of the Pak army carried out massacres, looting and arson on the other side of the Kirtankhola River and at 10 o'clock that day they crossed Kirtankhola River from Barishal by gunboat and entered Charkowa. But there is a contradiction among the researchers that several of them mentioned 30 August as the date of genocide at Charkowa. Accordingly, Charkowa genocide occurred on 30 August a 11 o'clock, (Marzan, 2020, p. 276) another source also illustrated the same date of Charkowa genocide, (Shaheen, 2018, p. 272) but when we interviewed and studied the field it has been proved 
without any hesitation that it was on 20 August, because some of them said 30th August, some said 20th August, some said 5 Bhadra, some said 15 Bhadra. This type of confusion would occure because, it had happend long time ago. But most of them confirmed among the respondent that it was on 20 August 1971. Besides, a memorial pillar was found in the grave of Tajumbar Ali Talukder (Arai Talukder) who was killed in the incident that day. The date of his death is written on that memorial pillar as 20 August 1971 . Based on these, we could be fairly sure about the date of the genocide and which was on 20 August. At 10/11 o'clock on that day first, they killed an old man named Raham Ali in front of Habib Master's house. Then they grabbed Tajumbar talukdar (Ari talukdar), who was weaving nets in the shop next to his house and set fire to his shop. At that moment grabbed Israil Ali, who were repairing the boat along with him they also grabbed Enayet from the paddy field and tied them up. They raided the ground near Dhalu Mollah's house and gathered a total of 12 people. On their way to Barishal, they tied up a total of 17 people, including Alam and a couple of pedestrians, those who were headed towards their home by Kheyaghat. On the other side of the river, they put everyone in the terminal with their tied hands. After $3 \mathrm{pm}$, the miscrients took everyone to the canal adjacent to the house of Moslem Ali Khalifa on the bank of Maragangi canal in front of the ice factory at Charkowa ferryghat. At first, they set fire to the house of Moslem Ali Khalifa and later, Pakistani forces shot 16 people standing on the bank of the canal. All of them were martyred except Motahar Hawladar. There was a boat in the canal and every death bodies were floating on the water of the canal. Nazrul Islam Chunnu (60), son of Moslem Ali Khalifa, an eyewitness to the massacre said, a man named Haijun, who was with the Pak aggressors, picked up the bodies from the canal and collected them in their backyard. The villagers took the bodies of their relatives to their homes at night. Among them, the body of Tajumbar Talukdar was buried by his close relatives at his house the next day. The other bodies were buried at night and the next day. However, the bodies of Shahjahan, Moffy and Taju were buried in a mass grave under a palm tree at Ishaq Chowkidar house. Besides, the two bodies floated in a pond next to the bamboo bushes of Moslem Ali Khalifa's house for about two days. When the fox fought with the dog's for tearing the body apart, the villagers including Moslem Ali Khalifa's son Chunnu Khalifa floated the bodies in the river. It was later learned that the two bodies belonged to the same family, father and son of Kagashura. According to eyewitnesses, about 16 people were martyred in the Charkowa massacre. Though they were martyred in Charkowa some of them were from outside Charkowa Union, as a result of this, it was quite tough to identify the body of all the martyrs and they are known until today. According to eyewitnesses, about 16 people were martyred in the Charkowa massacre. Though they were martyred in Charkowa some of them were from outside Charkowa Union, as a result of this, it was quite tough to identify the body of all the martyrs and they remained known until this study. Here it could be noted that among the 16 martyred in that genocide only 12 were identified and there were 04 unknown persons. Now we would like to include all the data of the identified martyred in the Charkowa genocide, which are below.

Table 1. The Details information of martyred in Charkowa genocide

\begin{tabular}{|c|c|c|c|c|c|c|}
\hline $\begin{array}{c}\text { S. } \\
\text { N }\end{array}$ & Name & Age & Occupation & Religion & Father's Name & Adress \\
\hline 01 & Enayet & 16 & Agriculture & Islam & $\begin{array}{l}\text { Mosharraf Hossain } \\
\text { Hawladar }\end{array}$ & Charkowa \\
\hline 02 & Md. Israil & 25 & Agriculture & Islam & Tobarak Ali & Charkowa \\
\hline 03 & $\begin{array}{c}\text { Taju (Tajul } \\
\text { Islam) }\end{array}$ & 40 & Milk seller & Islam & Unknown & Charkowa \\
\hline 04 & Muffi (Mofiz) & 15 & Milk seller & Islam & Tajul Islam & Charkowa \\
\hline 05 & Aziz & 25 & Agriculture & Islam & Unknown & Charkowa \\
\hline 06 & Tajumbar Ali & 50 & $\begin{array}{c}\text { Business (Grocery } \\
\text { shopkeeper) }\end{array}$ & Islam & Hasmat Ali & Charkowa \\
\hline 07 & Alam & 25 & Agriculture & Islam & Unknown & Charkowa \\
\hline 08 & Abdul Khaleq & 30 & Agriculture & Islam & Unknown & Charkowa \\
\hline 09 & Kamal & 25 & Agriculture & Islam & Unknown & Charkowa \\
\hline 10 & Siraj Uddin & 22 & Agriculture & Islam & Unknown & Charkowa \\
\hline 11 & Rahmali Khan & 60 & Agriculture & Islam & Unknown & Charkowa \\
\hline 12 & Shahjahan & 15 & $\begin{array}{c}\text { Business (Bread } \\
\text { Shopkeeper) }\end{array}$ & Islam & Unknown & Charkowa \\
\hline
\end{tabular}

Source: Collected and Prepared by the researchers

Here, it could be observed that majority of them among the identified martyred were below 30 year age and only a little portion of them were old or middle age. Besides, in terms of occupation they were mainly agriculturer and small businessman. Here it is interestinting to note that all martyred were Muslims and male, whereas not a single woman was tortured and raped which could be identified. Now question arise why the Pakistani army intended mass destruction in this area? The fact isn't very clear, because, if we look back to the 
strategies of genocide which were employed by the Pak army, it could be seen that they mainly applied two strategies; firstly, Eliticide, where they attempeted to kill the intellectuals which includes amcademics, cultural, media and even sports figures; Secondly, Politicide, by this strategy they killed and attempted to kill supporters of Awami League and Mukti Bahini.(Jones, 2014) In this case, the Pak army employed the second strategy, beccause here is notable that the people of this area were the mass supporter of Awami League and the leaders of the Mukti Bahini took place in this area. A sub group of Mukti Bahini were formed at Karnakathi leaded by Captain Omar, (Hasan, 2012, p. 38) which is not a fur away from the Charkowa. The members of this group of Mukti Bahini always partolled this area as part of free the Barishal from the Pak army. As because of this Pak army employed atrocities in this area and tried to destroy the support base of Mukti Bahini and killed innocent people as well as fired across the Charkowa village.

\section{Concluding Remarks}

On the question of Charkowa genocide this paper intended to explore the details history of Charkowa genocide. Through this journey, it first explored the socio-political and overall geographical situation of Charkowa union, where it could be found that though this area is closely related to the Barishal town but it was quite a bit underdeveloped in the sense of educational, economical and political background, but after the begun of liberation war the people of this area tried to protected Pakistani atrocities. Along with other areas of Barishal, they also formed a subgroup of Mukti Bahini under the leadership of Captain Omar at the Karnakathi. As part of the regular destruction of the Pak Army, they entered into the Charkowa union in two separate groups and killed 16 innocent people whereas one of the injured and successfully escaped from the destructed area on 20 august 1971. Overall, it could be said in the conclusion that the Charkowa genocide was a part of the preplanned of Pak Army, where they were taking part alone except the support of the peace committee and Al Badar Bahini. Furthermore, the Charkowa massacre was not only involved killings but also arson and looting of their homes and shops. Besides, on the day of the genocide, the Pakistani forces captured everyone in the morning and carried them back in the afternoon and finally after the genocide, the Pakistani forces quickly left the area. Here is interesting to note that in this genocide, besides the locals of Charkowa Union, outsiders were also killed.

\section{References}

Bloxham, D. \& Moses, A. D. (2010). The Oxford handbook of genocide studies. (1 ${ }^{\text {st }}$ ed.). Oxford: Oxford University Press. doi: 10.1093/oxfordhb/9780199232116.001.0001.

Hasan, M. et. al. (2012) Muktijuddhe Barishal: Pratyakkhadarshee O Angshagrahankarir Bibaran. ( ${ }^{\text {st }}$ ed.) Dhaka: Mowla Brothers.

Horvitz, L. A. \& Catherwood, C. (2006). Encyclopedia of war crimes and genocide. (1 ${ }^{\text {st }}$ ed.). New York: Facts On File, Inc.

Jones, D. A. (2014). The Bangladeshi Genocide in Comparative Perspective, Liberation War Museum. Available at: https://www.liberationwarmuseumbd.org/anniversary-lecture-adam-jones-14/. (Accessed: 25.01. 2021)

Marzan, L. A. (2020). "Charkowa Ganohatta," Rashid, H. O.(ed) Bangladesh Muktijuddah Gayankos, (1 ${ }^{\text {st }}$ ed.). Dhaka: Bangladesh Asiatic Society.

Ministry of Information (2020). The Historic $7^{\text {th }}$ March Speech of the Father of the Nation Bangabandhu Sheikh Muibur Rahman, (1 ${ }^{\text {st }}$ ed.). Dhaka: Department of Films and Publications.

Quaderi, F. Q. (2015). Genocide , 1971, Banglapedia: National Encyclopedia of Bangladesh. Available at: http://en.banglapedia.org/index.php?title=Genocide,_1971\&oldid=20786. (Accessed: 12.12. 2020)

Rashid, H. O. (2018) Sat-E Marcher Bhason-Keno Biswa-Oitijjaya Sampad: Bangabandhu Muktiuddah Bangladesh, ( $1^{\text {st }}$ ed.). Dhaka: Bangla Academy.

Shaheen, M. M (2018) "Barishal 1971: Ganahattar Itibritto O Prokrity," Itihas Sammiloni Probandha Sangra. 7. pp. 269-308.

Sheren, S. M. (2015). The War of Liberation, Banglapedia: National Encyclopedia of Bangladesh. Available at: http://en.banglapedia.org/index.php?title=War_of_Liberation,_The\&oldid=20866. (Accessed: 05.12. 2020)

UN (1951). Convention on the Prevention and Punishment of the Crime of Genocide, United Nations Audiovisual Library of International Law. Paris: UN General Assembly. doi: 10.5771/9783845258911.

UN (2020). Genocide, United Nations Office on Genocide Prevention and the Responsibility to Protec. Available at: https://www.un.org/en/genocideprevention/genocide.shtml. (Accessed: 12.01. 2021) 